Aleksandar Vujovic

Assistant Professor

Faculty of Mechanical Engineering Podgorica, University of Montenegro Montenegro

Zdravko Krivokapic

Full Professor

Faculty of Mechanical Engineering Podgorica, University of Montenegro Montenegro

Rade Grujicic

Faculty of Mechanical Engineering Podgorica, University of Montenegro Montenegro

Jelena Jovanovic

Assistant Professor Faculty of Mechanical Engineering Podgorica, University of Montenegro Montenegro

Ana Pavlovic

Department of Industrial Engineering Alma Mater Studiorum University of Bologna

\section{Combining FEM and Neural Networking in the Design of Optimization of Traditional Montenegrin chair}

The paper presents the results of tests and analysis of strength of traditional Montenegrin chair using FEM (The Finite Element Method) according to the procedure described in the relevant European standards. Stresses in the critical points of the structure were obtained and compared with values of permissible stresses for appropriate material. The influence of design parameters of chair on distribution and intensity of the stresses was considered, so it was selected the appropriate combination of parameters that presents the optimal solution from the aspect of the mentioned criterion. The obtained solution is compared with a volume equivalent model of usual chair with four legs. Based on the results we trained neural network in order to make it enable selection of design parameters of the traditional Montenegrin chairs that provide a satisfactory solution

Keywords: Traditional Montenegrin chair, FEM, neural networks, optimization, European standards

\section{INTRODUCTION}

The traditional Montenegrin chair ("Stolovaca") is a traditional piece of furniture in Montenegro. The name, according to tradition, originates from the verb "sit" govern, manage and, due to the fact that patriarchy is expressed in the Montenegrin regions, in the households it was a part of the furniture on which usually only the head of the household was sitting.

Recommendations for the choice of materials for its production are the result of experience. The seating panel (seat) is usually made of spruce, while the rest is mostly made of beech wood. Spruce is taken because it is lighter and less prone to distortion (bending) compared to deciduous trees, which is very important considering the fact that the sizes of the panel are large. Its advantage in comparison to other conifer is reflected in the fact that there is usually no resin bag (as opposed to pine) and that it is lighter (for example, than fir tree). For making the other parts of Montenegrin chair, the following can be used along with beech: maple, ash, oak, walnut, pear (suitable for carving), or other timber of higher load capacity, although beech is often chosen due to the fact that it is widespread in this region.

Mechanical properties of the same types of wood [1, 2], vary from region to region and some of them are presented in Table 1.

Montenegrin chair compared to conventional chairs with four legs shows the following advantages:

- considering that the plane is defined by three non collinear points, the reliance is made through three

Received: May 2016, Accepted: June 2016

Correspondence to: Prof. Aleksandar Vujovic

Faculty of Mechanical Engineering Podgorica

Unievrsity of Montenegro, Montenegro

E-mail: aleksv@ac.me

doi:10.5937/fmet1604374V

(C) Faculty of Mechanical Engineering, Belgrade. All rights reserved and not four legs, thus saving materials;

- saving of materials is also reflected in the fact that in a chair with four legs for supporting the seat plate and connecting the legs in order to increase the stability of the chair additional slats are needed (Figure 1), which are not present in Montenegrin chair;

- in order not to come to the wobbling of the chair, the base on which the four-legs chair is put needs to be ideally flat, while the chair with three legs will not wobble on uneven surfaces;

- although the layout is a matter of taste, it can be concluded that from the aesthetic, but also the ergonomic viewpoint the Montenegrin chair is in advantage compared to traditional chair with four legs, among other things because of its unusualness.

Table 1. Comparison of the mechanical properties of American and European wood-based materials.

\begin{tabular}{|l|c|c|c|c|}
\hline \multirow{2}{*}{} & \multicolumn{2}{|c|}{$\begin{array}{c}\text { According to [Forest } \\
\text { Products Laboratory } \\
\text { USDA] }\end{array}$} & \multicolumn{2}{|c|}{$\begin{array}{c}\text { According to } \\
\text { [European } \\
\text { Wood] }\end{array}$} \\
\cline { 2 - 5 } & Spruce & Beech & Spruce & Beech \\
\hline $\begin{array}{l}\text { Density }\left(\mathrm{kg} / \mathrm{m}^{3}\right) \\
\text { Modulus of } \\
\text { elasticity (MPa) }\end{array}$ & 440 & 640 & 441 & 712 \\
\hline $\begin{array}{l}\text { Modulus of } \\
\text { rupture (MPa) }\end{array}$ & 72 & 103 & 77 & 123 \\
\hline $\begin{array}{l}\text { Tension } \\
\text { strength (MPa) }\end{array}$ & 84,8 & 86,2 & 95 & 135 \\
\hline $\begin{array}{l}\text { Compression } \\
\text { strength (MPa) }\end{array}$ & 39 & 50,3 & 44 & 62 \\
\hline
\end{tabular}

As the fiddle represents a traditional Montenegrin instrument which Montenegrins have been proud of trzing to decorate it with a variety of motifs, so the 
owners devoted time to finesses of Montenegrin chair trying to carve and shape it, leaving in some way their own mark. Thus, they all introduced some novelty, either large or small, and over time its design changed and the experience crystallized the most appropriate one (Figure 2).

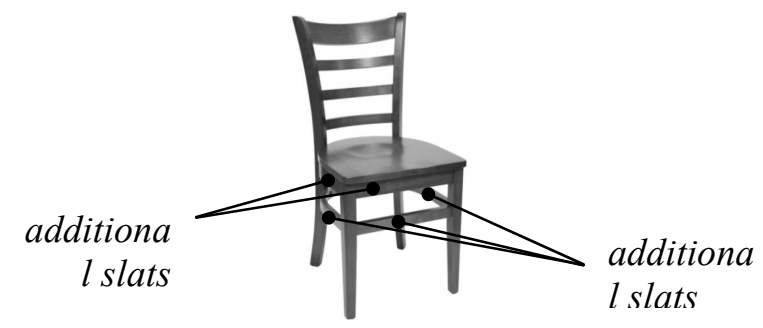

Figure 1. Additional slats for increased stability of ordinary chair

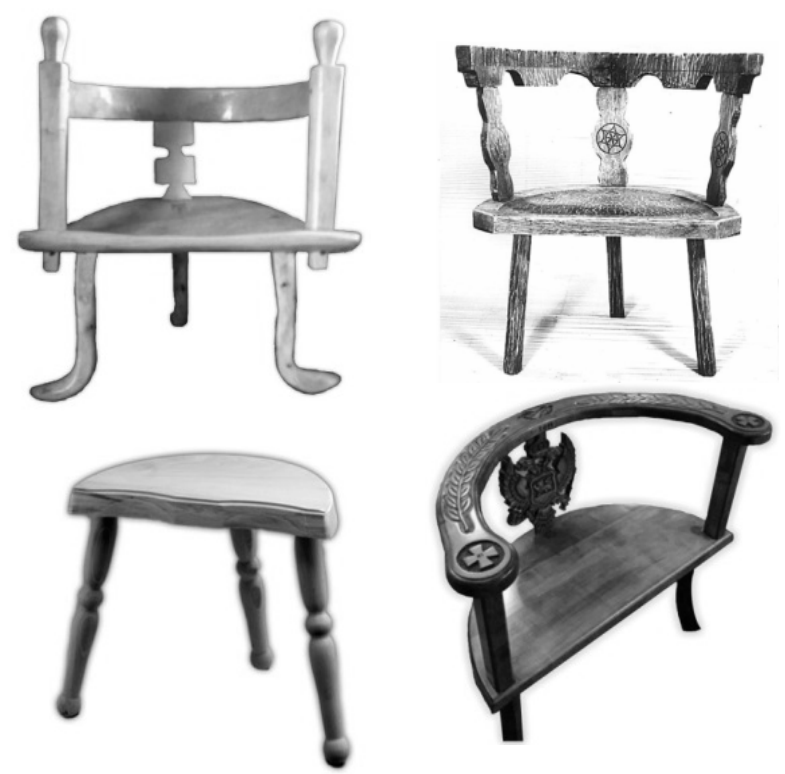

Figure 2. Different forms of Montenegrin chair

The backrest is shaped so that space for supporting the back is higher and thinner, becomes reduced and the spread as it follows from the back to "apples" that fall into the palm (Figure 3). This form of backrest enables proper reliance of both arms and back. The trestles have a slightly rounded shape and slantwise position to increase seat capacity and stability.

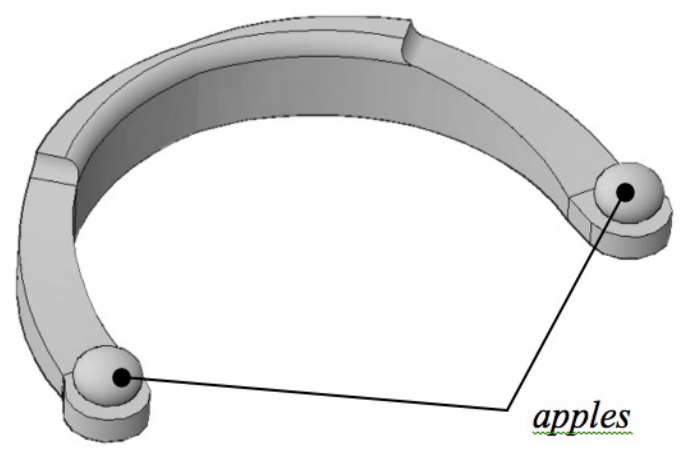

Figure 3. The backrest and handrail of Montenegrin chair

\section{OBJECTIVES AND HYPOTHESIS OF THE PAPER}

Testing the strength, durability and safety of furniture is done according to the procedure explained in the standards MEST EN 12520 [3] and MEST EN 1728 [4]. In static testing of chairs strength a standard default value of external load is set through an appropriate tool (Figure 4.) by menas of which the load is transferred to the seating pad and is considered that the observed chair meets the criterion of strength if it doesn't come to its breaking or permanent damage after testing in accordance with MEST EN 12520.

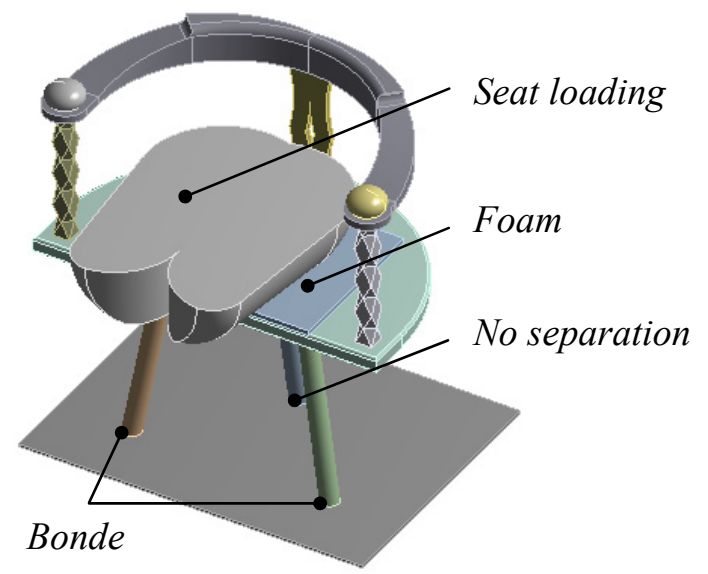

Figure 4. Montenegrin chair and tool for testing static strength.

One of the aims is the optimization of the structural parameters of Montenegrin chair from the aspect of static strength using FEM and neural networks. Thereat, the following parameters were taken into account:

a) the thickness of the seating panel;

b) the thickness of the legs;

c) the front legs distance;

d) the tilting angle of the legs (the angle that the axis forms with the corresponding gravity line of the triangle formed by the legs).

The hypothesis of this paper is: using FEM and neural networks can optimize relevant parameters of the Montenegrin chair.

\section{EXPERIMENTAL RESEARCH USING THE FINITE ELEMENT METHOD}

To determine the moment in which there will come to the chair fracture, the equivalent von-Mises's stresses were measured at critical points of the structure, i.e. the points of junction of legs with the seat. The assumption was introduced that fracture occurs at the moment when the stress value exceeds the lowest of the values set out in Table 1. For the purpose of testing, the ANSYS program was used based on the finite element method. The model of the traditional Montenegrin chair was drawn with a variation of the above mentioned parameters. Additionally, the tool is drawn in accordance with the dimensions given in clause 5.4 of standard MEST EN 1728. Among the tools and the seat plate foam is placed, and the load of $1.3 \mathrm{kN}$ is given by means of tools. The standard MEST EN 1728 provides that during the static test of chair strength with four legs in the testing machine the last two legs of the chair are fixed to prevent it from slipping during the test. 
Analogously, a solid connection (bounded) of the front legs of the Montenegrin chair and the base is defined in the software, while between the third (rear) leg and the base the type of contact no separation is defined (the connection which does not separate the body, but it provides a very little slippage (without friction) of one body over another).

In order to obtain more accurate data, at critical points, i.e. the point of junction of legs with the seat, spheres of influence were formed in which the finer finite element mesh was defined compared to the rest of the structure.

For each of the four input parameters three values have been taken:

a) the thickness of the seating panel: 10, 20, $30(\mathrm{~mm})$;

b) the thickness of the legs: 15, 25, $35(\mathrm{~mm})$;

c) the legs distance: $380,480,580(\mathrm{~mm})$;

d) the tilting angle of the legs: $75,80,85\left(^{\circ}\right)$.

For each combination of the previously reported values the maximum stress was determined, giving a total of 81 analyses. The obtained results are shown in table 2 .

Table 2 shows that from the stated input values the minimum stress $(5 \mathrm{MPa})$ is provided by the combination of the following parameters: panel thickness $30 \mathrm{~mm}$, thickness of legs $35 \mathrm{~mm}$, legs distance $380 \mathrm{~mm}$ and the angle of the legs $80^{\circ}$. It was completely expected that the smallest stresses occurred for the thickest plate and the thickest legs. In the arrangement with stresses lower than the allowable, the stresses variation is quite small with a changing range and legs tilt. However, with the increase of the stresses, the variation is greater in their values with the change of the parameters mentioned above. Minimum stress is much lower than all limit stresses set out in Table 1, which means that this chair can withstand much higher loads than those of the standard MEST EN $12520(110 \mathrm{~kg})$.

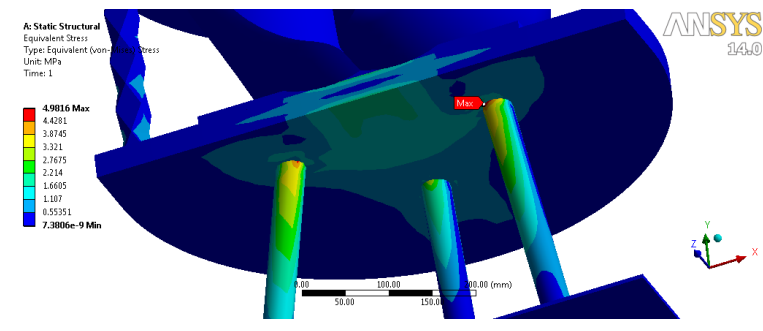

Figure 5 (a). The arrangement of von-Mises's stresses at the Montenegrin chair

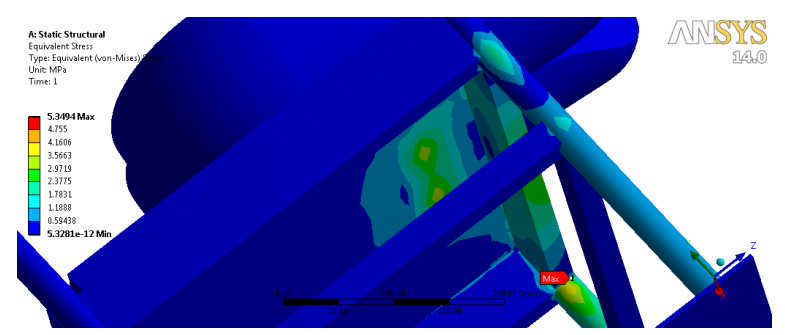

Figure 5 (b). The arrangement von-Mises's stresses at the usual chair with four legs.

The solution with minimal von-Misses stresses was compared with a volume equivalent constructive solution for the usual chair with four legs. Their volumes are at $10,57 \cdot 10-3 \mathrm{~m} 3$. Distribution of stresses obtained according to the previously described procedure is shown in Figure 5. The network was selected with a maximum size of elements of $20 \mathrm{~mm}$, and in the contact of legs with a seat plate spheres of influence were formed of the radius of $50 \mathrm{~mm}$ with a maximum size of elements of $5 \mathrm{~mm}$. Such a network in the Montenegrin chair consisted of 38969 elements and 122442 nodes, and in a chair with four legs 31622 elements and 101104 nodes.

Table 2. Dependence of maximum stresses on design parameters of Montenegrin chair.

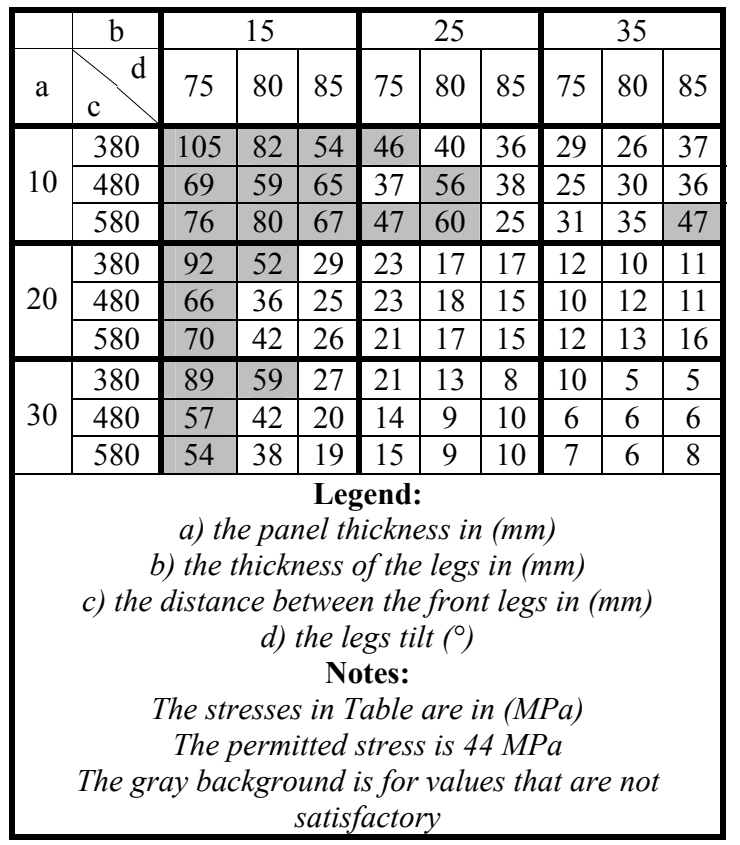

On the basis of the previous figure it is observed that the maximum stresses in both cases are approximately equal.

\section{APPLICATION OF NEURAL NETWORKS IN OPTIMIZATION FUNCTION}

Artificial neural networks are useful for a great number of inputs over a short period of time and when the connectivity of the data is not known [5]. Artificial neural networks are evolutionary optimization-based algorithms developed by [6] and [7]. A neural network is defined by the neurons and their connections. All neurons are organized into layers; the sequence of layers defines the order in which the activations are computed [8].

Back propagation is the best known and widely used learning algorithm in training multi-layers, such as the Feed Forward Neural Networks [9]. The architecture of the Feed Forward Back-propagation Neural Network is presented in [10]. Back-propagation provides a computationally efficient method for changing the weights in the Feed Forward Neural Network. In [11] proposes that the prediction accuracy increases when the Back-propagation Neural Networks are applied and as the number of hidden neurons increases. For these reasons, the current research uses a Feed Forward Backpropagation Neural Network with a higher number of hidden neurons to obtain faster convergence. 
For the purposes of this paper, work with neural networks is implemented in the software package Matlab. The rapid rise of this software package is accomplished by the development of the possibility of upgrading the modular type, i.e. the development of additional modules, the so called, Toolboxes that complement MATLAB "by the functions of interest for a certain mathematical and engineering disciplines" [12]. One of the modules and Neural Network Toolbox includes functions for the design and simulation of neural networks.

Neural Network Toolbox provides complete engineering of neural network in MATLAB environment, starting from design through training to simulation of a variety of neural network algorithms [13]. The main application of this tool is reflected in [14, 15 and16]:

- approximation and modeling of the functions;

- $\quad$ signal processing;

- forecasting, classification and grouping of data.

To build the Neural Network (Results presented in Back propagation Neural Network), the data must inputted into the software package MATLAB. The training set for the neural network represents a set of data given in the earlier introduced Table 2.

For this set of input data Feed Forward Back propagation Neural Network is created which is shown in Figure 6 . The best results on the training sample has made network with five layers of neurons, each of which has per 25 neurons and the last as a rule 1. Thus the selected network, trained at the set of selected input data has performances of progress, as in Figure 7 . Figure 8 (a) shows the regression model of trained network where a very good convergence is observed as evidenced by the output and the value of errors in Figure 8 (b).

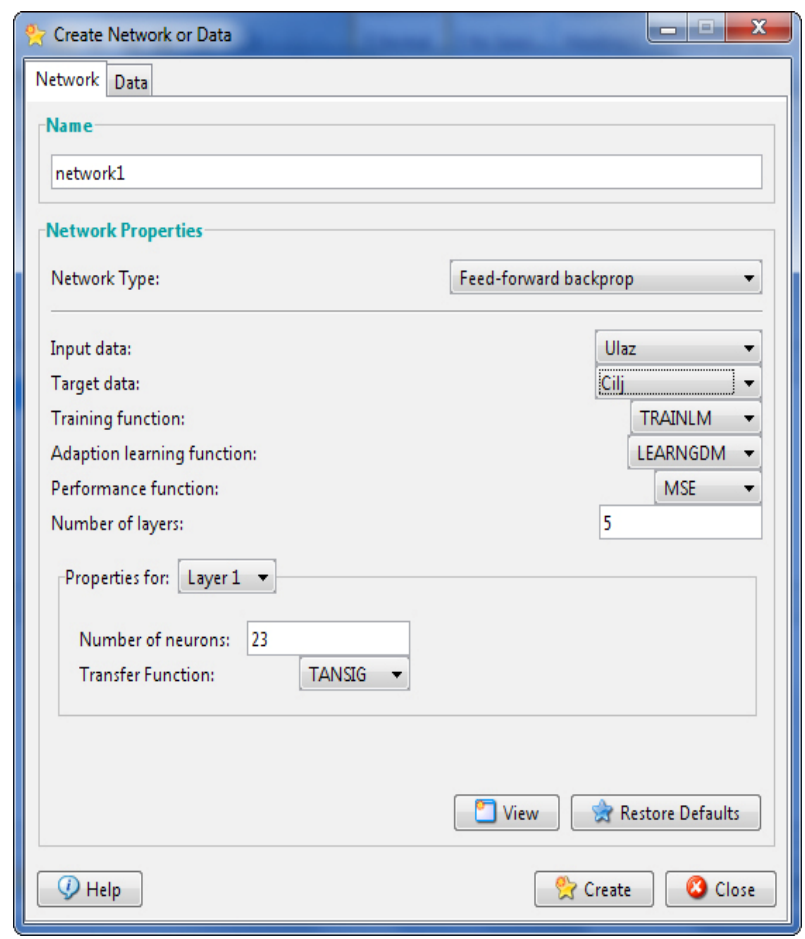

Figure 6. A Model of Feed forward Back-propagation Neural Network.
Testing of such network training was conducted at three examples. The first example is extracted from the training sample as follows: (the plate thickness: 10; the thickness of the legs: 15; the legs distance: 380; the legs tilt: 75). The test results in this case show a very good agreement (Figure 9).

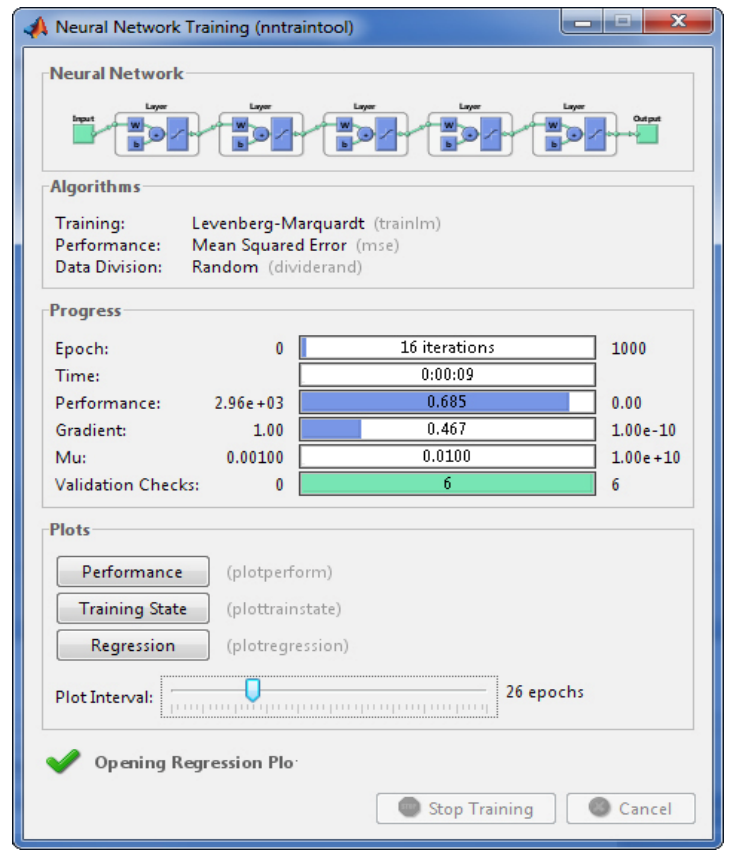

Figure 7. Training progress of Feed forward Backpropagation Neural Network.

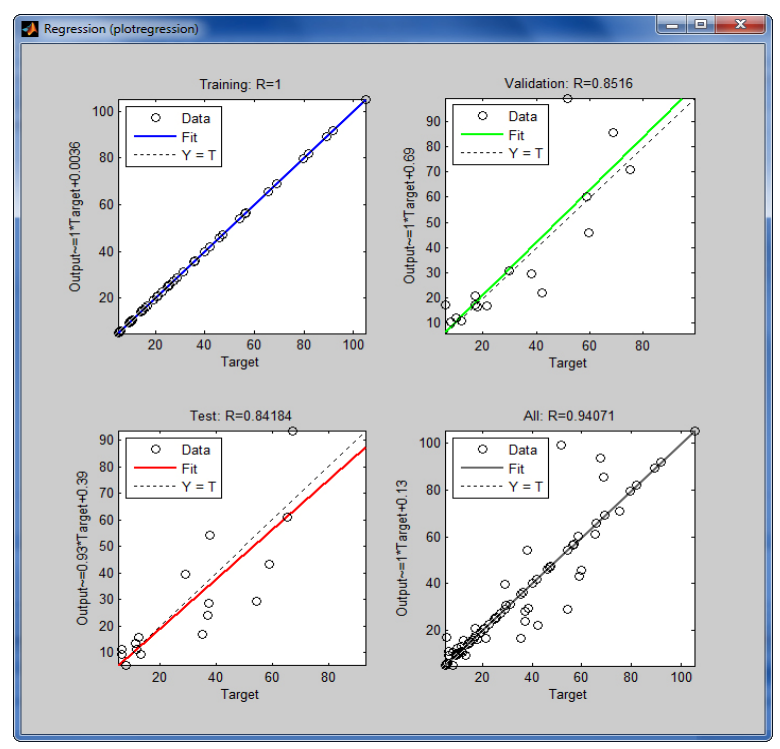

Figure 8. Results of training of Feed forward Backpropagation Neural Network.

a)

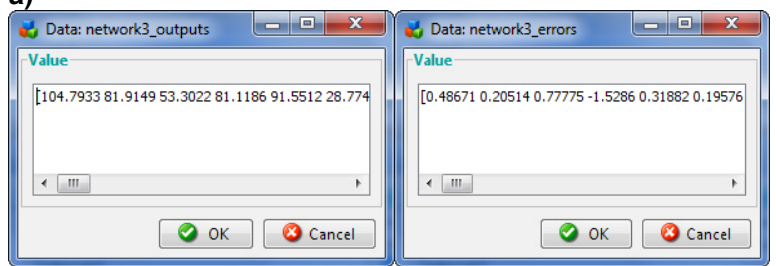

b) 


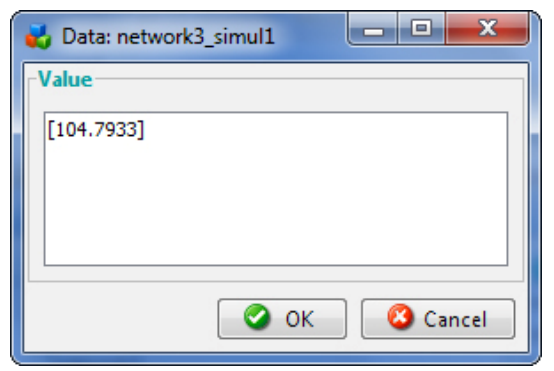

Figure 9. The results of the tests on the sample 1.

The network was tested for another two test samples from the scope of the training sample but do not coincide with them, as follows:

a) The plate thickness: 18; the thickness of the legs: 30; the legs distance: 450; the legs tilt: 77;

b) The plate thickness: 12; the thickness of the legs: 15; the legs distance: 440; the legs tilt: 76 .

The results of testing on these examples are shown in Figure 10 (a) and 10 (b).

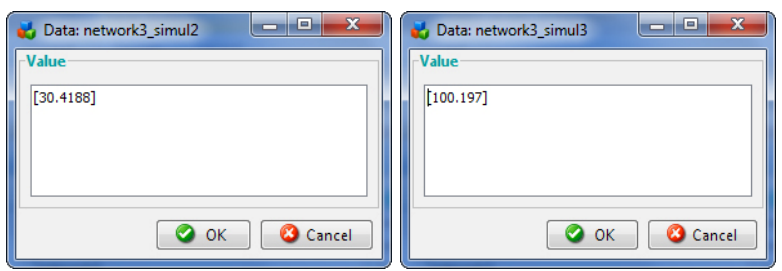

Figure 10. The results of the tests on 2 test samples.

The test results shown in Figure 10 indicate logical results in relation to the Table 2 . The result lower than 44 , which relates to a state of stress indicates that the chair is satisfactory as is the case in Figure 10 (a), i.e. to a unsatisfactory result as in the case of the Figure 10 (b).

\section{CONCLUSIONS}

This paper is based on the application of FEM and neural networks on a traditional Montenegrin chair ("stolovaca"). Bearing in mind that the majority of producers in Montenegro returns to the original shape of furniture, the traditional Montenegrin chair appears as a demanded product.

For this particular shape (chair with three pillars) the appropriate standards for testing do not exist. This lack of standards has caused that on the basis of the same density values of the chair with four legs and the traditional Montenegrin chair optimizing of relevant parameters of the Montenegrin chair is performed (thickness of the seat plate, the thickness of the legs, the distance between legs and the angle of the legs).

Modelling by using FEM [17] was implemented with the assumption that fracture occurs at the moment when the stress value exceeds the strength of the material. In this way, the data (data 81) were provided which served for the neural network training and testing. The trained neural network enables that for the variation of parameters the optimal solution is reached (e.g. minimum size), which confirms the starting hypothesis. But this paper also confirms the advantages related to the use of neural networks as a support for designers.

The next fundamental step in this research deals with the desire to investigate in the future the applicability of the neural networks when multiple conditions have to be simultaneously optimized. In that case, characterized by a larger complexity, the procedure cannot benefit of a single formula to be minimized or maximized, anymore. On the contrary, an $\mathrm{N}$-dimensional space for optimization emerges with the necessity to define optimization laws, acting at an upper level, before any final decision. It happens, for instance, when the chair design has to be optimized not only on the basis of a stress-strain relation (mainly related to the product's safety), but also considering additional aspects as costs, lead time, etc... Miscellaneous parameters related to the wood manufacturing, as machine tools, tools, productivity and many others have to be taken in count $[18,19,20,21]$. Also, in this case neural networks can represent a valid approach, but instead of implementing complex networks and elaborated training procedures, it is sometimes preferable to couple them with alternative fuzzy code (as genetic algorithms). All these aspects will be investigated soon.

\section{ACKNOWLEDGEMENT}

This research was realized as part of the Adria-Hub project, a transnational collaborative action implemented with the support of the European Union inside the Adriatic IPA CBC Programme. Additional details in [22].

\section{REFERENCES}

[1] Forest Products Laboratory USDA,: Wood Handbook; Wood as an Engineering Material. Forest Service, United States Department of Agriculture, Madison: Wisconsin, 1999.

[2] European Wood, Available at: http://jp.european wood.org/en/living-with-wood/selected-europeanwood-species/

[3] MEST EN 12520:2010. Furniture - Strength, durability and safety - Requirements for domestic seating

[4] MEST EN 1728:2013. Furniture - Seating - Test methods for the determination of strength and durability

[5] Arsovski Z.: Informacioni sistemi (Information systems), Kragujevac, Serbia: University of Kragujevac, Faculty of Economics, 2008.

[6] Ozdemir D. and Temur GT, DEA ANN approach in supplier evaluation system, World Academy of Science, Engineering and Technology, Vol.54, No. 538, pp. 343-348, 2009.

[7] Li, Qian.: An ANN pruning algorithm based approach to vendor selection, Kybernetes, Vol. 38, No. 3/4, pp. 314-320, 2009.

[8] Kumar J. and Roy N.: A Hybrid Method for Vendor Selection using Neural Network, International Journal of Computer Applications, Vol. 11, No. 12, pp. 35-40, 2010.

[9] Choudhary A. and Rishi R.: Improving the Character Recognition Efficiency of Feed Forward BP Neural Network, International Journal of Computer Science \& Information Technology,; Vol.3, No.1, pp. 85-96, 2011. 
[10] Tiwari S., Kumar SA. and Shukla VP.: Statistical Moments based Noise Classification using Feed Forward Back Propagation Neural Network, International Journal of Computer Applications, Vol.18, No.2, pp. 36-40, 2011.

[11] Jin J., Liang DL., Bao Y. and Huang GX.: A committee machine with two-layer expert nets. Kybernetes, Vol.39, No.6, pp. 961 - 972, 2010.

[12] Ćalasan L, Petkovska M.: MATLAB $i$ dodatni moduli Control System Toolbox i Simulink, Mikro knjiga, Beograd, 1996.

[13] Jovanović J., et al.: Evaluation of environmental impacts using Backpropagation Neural Network, Kybernetes, Vol.42, No.5, pp. 698 - 711, 2013.

[14] MATLAB. Neural Network Toolbox - For Use with MATLAB, The Math Works, 2004.Demuth H, Beale M, (2000). Neural Network Toolbox - For Use with MATLAB. The MathWorks, 2000.

[15] Klem, N. Informatika, Uvod u MATLAB. Beograd, 2006.

[16] Pavlovic A., Fragassa C.: Numerical modelling the ballistic impacts on flexible curtains used as safety protection in woodworking. Proceedings of the Institution of Mechanical Engineers, Part C: Journal of Mechanical Engineering Science, DOI: 10.1177/0954406216646401

[17] Pavlovic A., Fragassa C.: Analysis of flexible barriers used as safety protection in woodworking. International Journal of Quality Research, Vol.10 No.1, pp. 71-88, 2016.

[18] Lucisano G., Stefanovic M. and Fragassa C.: Advances Design Solutions for High-Precision Woodworking Machines. International Journal of Quality Research, Vol.10, No.1, pp. 143-158, 2016.

[19] Fragassa C., Zigulic R. and Pavlovic A.: A Practical Guideline for the Design and Use of Tools in Woodworking. Tehnicki Vjesnik - Tehnical Gazette, Vol.23, No.3, 2016.
[20]Zivkovic I., Pavlovic A. and Fragassa C.: Improvements in wood thermoplastic composite materials properties by physical and chemical treatments, International Journal of Quality Research, Vol. 10, No. 1: pp 205-218, 2016.

[21] Savoia M., Stefanovic M. and Fragassa C.: Merging Technical Competences and Human Resources with the Aim at Contributing to Transform the Adriatic Area in a Stable Hub for a Sustainable Technological Development, International Journal of Quality Research, Vol.10, No.1, pp. 1-16, 2016.

\section{КОМБИНАЦИЈА МКЕ И НЕУРОНСКИХ МРЕЖА У ДИЗАЈНУ И ОПТИМИЗАЦИЈИ ТРАДИЦИОНАЛНЕ ЦРНОГОРСКЕ СТОЛИЦЕ}

\section{А. Вујовић, 3. Кривокапић, Р. Грујучић, Ј. Јовановић, А. Павловић}

У раду су приказани резултати испитивања и анализе отпорности традиционалне црногорске столице користећи МКЕ (метода коначних елемената), у складу са поступком описаним у релевантним европским стандардима. Напрезања у критичним тачкама структуре су добијена и упоређена са вредностима дозвољених напона одговарајућих материјала. Утицај параметара дизајна столице на дистрибуцију и интензитет напона је узет у обзир, тако да је изабрана одговарајућа комбинација параметара који представља оптимално решење са аспекта поменутог критеријума.

Добијено решење се пореди са еквивалентним моделом запремине уобичајене столице са четири ноге. На основу резултата смо испитали неуронске мреже како би то омогућило избор праметара дизајна традиционалне црногорске столице које пружају задовољавајуће решење. 